\title{
Response of soil nutrients to typical plant and engineering measures for soil and water conservation in northern rocky mountain area of China
}

\author{
Liangyi Rao ${ }^{1}$, Yue Qian ${ }^{1}$, and HeLing Liu ${ }^{1}$ \\ ${ }^{1}$ Beijing Forestry University
}

July 27, 2020

\begin{abstract}
Nine slope runoff plots with different soil and water conservation measures were selected in Baima small watershed of Pingshun County, Shanxi Province of China, to explore more effective soil and water conservation measures to avoid soil nutrient losses, improve soil fertility, and control non-point source pollution. Soil organic carbon (SOC), total nitrogen (TN) and available potassium (AK) were determined and compared in this paper. The results show that,1) In grass measures, sowing of both riochloa is chaemum are more suitable for nutrient protection on the upper slope, fertility and the whole nutrient content of natural grass is optimum (SOC:24.86g/kg, TN:2.09g/kg, AK:157.00mg/kg);2) Plant combined with engineering measures ,in different plant measures(fish-scale pit), shrubs are more suitable for nutrient conservation on the upper slope. SOC (25.04g/kg) and TN $(2.13 \mathrm{~g} / \mathrm{kg})$ contents of coniferous trees were the highest, and AK $(170.89 \mathrm{mg} / \mathrm{kg})$ content of broad-leaved trees was the highest;3) Plant combined with engineering measures , among the different engineering measures(oriental arborvitae), the overall nutrient condition of level bench was the best (SOC: $33.33 \mathrm{~g} / \mathrm{kg}, \mathrm{TN}: 2.21 \mathrm{~g} / \mathrm{kg}$, AK: $139.44 \mathrm{mg} / \mathrm{kg}$ ), and the stone dike terrace was poor (SOC: $18.19 \mathrm{~g} / \mathrm{kg}$, TN: $1.53 \mathrm{~g} / \mathrm{kg}, \mathrm{AK}: 118.11 \mathrm{mg} / \mathrm{kg}$ );4) The most suitable soil and water conservation measure was level bench of coniferous tree combine 9 measures. Soil nutrient contents are determined by plant characteristics, engineering measures and soil loss. In all plots, there were significant correlations between the three nutrients $(\mathrm{P}<0.01)$, showing an strong effects of conservation measures on soil nutrients.
\end{abstract}

\section{Hosted file}

LY RAO et al..Response of soil nutrients to measures in northern rocky mountain area.doc available at https://authorea.com/users/346472/articles/472461-response-of-soil-nutrientsto-typical-plant-and-engineering-measures-for-soil-and-water-conservation-in-northernrocky-mountain-area-of-china 


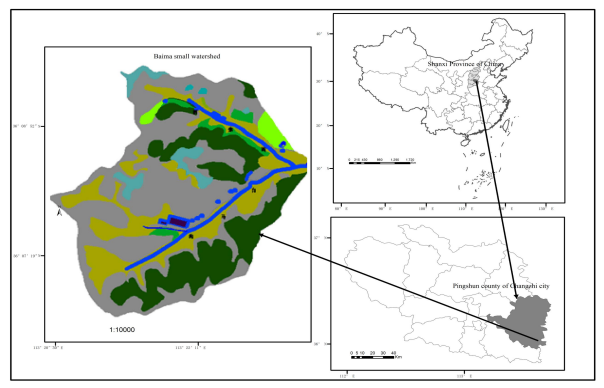

FIGURE 1 The study location

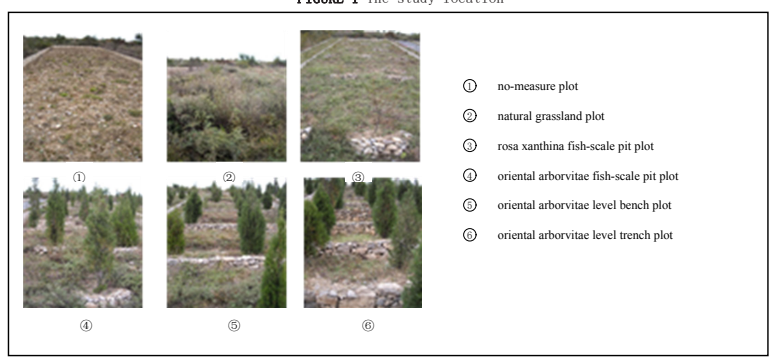

FIGURE 2 The runoff plots of comprehensive observation station in Baima small watershed 